\title{
Digital Visuality in Cultural Identity Construction: Notes from the Festival of Pacific Arts
}

La visualité digitale dans la construction d'identité culturelle: Notes du Festival des Arts Pacifique

Jari Kupiainen

\section{(2) OpenEdition Journals}

Electronic version

URL: http://journals.openedition.org/jso/7605

DOI: $10.4000 /$ jso.7605

ISSN: $1760-7256$

\section{Publisher}

Société des océanistes

\section{Printed version}

Date of publication: 31 December 2016

Number of pages: 131-142

ISSN: 0300-953x

Electronic reference

Jari Kupiainen, « Digital Visuality in Cultural Identity Construction: Notes from the Festival of Pacific Arts », Journal de la Société des Océanistes [Online], 142-143 | 2016, Online since 31 December 2018, connection on 01 May 2019. URL : http://journals.openedition.org/jso/7605 ; DOI : 10.4000/jso.7605 


\title{
Digital Visuality in Cultural Identity Construc- tion: Notes from the Festival of Pacific Arts
}

by

\author{
Jari KUPIAINEN*
}

\begin{abstract}
In July 2012 in Solomon Islands, 27 different Pacific nations came together for two weeks for the 11th Festival of Pacific Arts to express and articulate their traditions in their present forms for other Pacific Islanders (few nonPacific Islanders attended the event). The festival was all about producing, reproducing and transforming Pacific identities, and much of this took an explicitly visual form, which the festival context fully supported. Cameras were everywhere and shooting was continuous both in photography and video, among the audience, the performers and the organizers as well. The photos were quickly transformed into YouTube, Facebook and offline video files, Flickr photo albums and countless other forms and formats shared among and between Pacific communities online and offline. The paper analyses this visual production in the cultural framework of Rennell and Bellona Islanders that the author has been working with. In particular, it highlights issues of cultural identity construction and aspects of cultural agency related with this visual production in the context of the overall modernization of the Solomon Islands society.
\end{abstract}

KEYwords : Solomon Islands, Festival of Pacific Arts, Rennell and Bellona, digital visual identity, digital bonding, selfie

The global reachability of digital communication technologies and the ubiquitous presence of related gadgets and applications even in remote places is a widely known fact, yet less is known of these processes and outcomes in societies where the shift from technological margins into digital environments occurs rapidly and coincides with the overall modernization of local societies. In

\section{RÉSUMÉ}

En juillet 2012, aux îles Salomons, 27 nations océaniennes se sont rassemblées durant deux semaines à l'occasion du onzième Festival des Arts du Pacifique, pour exprimer et mettre en avant - aux yeux d'autres insulaires du Pacifique (peu de non-îliens assistaient à l'événement)leurs traditions dans leur forme actuelle. Il s'agissait avant tout de (re)produire et transformer les identités du Pacifique, tout particulièrement à travers des formes visuelles. Les appareils photos étaient omniprésents et la prise d'images permanente, par les membres du publique, les performeurs et les organisateurs. Les images étaient rapidement diffusées via YouTube, Facebook, des albums photos Flickr ainsi que de très nombreux autres formats, échangés à l'intérieur de et entre les différentes communautés. Cet article analyse la production visuelle des groupes culturels de Rennell et Bellona, avec lesquels l'auteur a travaillé. Les questions de la construction des identités culturelles et de l'agentivité culturelle liée à cette production visuelle seront particulièrement mises en avant, dans le contexte plus large de la modernisation de la société des îles Salomon.

Mots-CLÉs : îles Salomon, Festival des Arts du Pacifique, Rennell et Bellona, identité visuelle digitale, digital bonding, selfie

modernization, traditional societies are forced into fundamental changes in all domains of social life, not least in terms of cultural identity and its representation. Digitalisation and digital technologies are presently integral elements in any modernization processes, which we may describe as digital modernity.

According to Miller and Horst (2012: 4), 
"the digital, as all material culture, is more than a substrate; it is becoming a constitutive part of what makes us human."

The statement highlights the importance of the digital in contemporary social life including the construction of cultural identities, but it also issues the relevance and urgency for studies of digitality in culture and society; or better, studies of digitality in a variety of cultures and societies, for it is not to be expected that digital processes would follow the same trajectory or produce identical outcomes in different cultures and societies. Rather, in order to establish a better analytical understanding of digitality in culture and society in the framework of digital modernity, we should be especially focusing on case studies among different cultural groups to examine this diversity of digital strategies and approaches, and also their impact on the construction of contemporary cultural identities.

Digital elements in people's identities, or digital identities, become constructed and established in any and all activities producing (numerical) digital content. These result from using computers, mobile phones, Internet and social media services, digital cameras and other digital gadgets (e.g. game consoles, GPs devices). They all leave electronic traces of use that together construct a person's digital identity. Such electronic traces will contain a wide assortment of different data, ranging from the gadget's technical usage logs to social media content, and more.

The inflation of social life in the digital domain would indicate that fresh forms of social practice are emerging there. This article addresses the issue of digital sociality through an analysis of digital cultural identities and digital bonding in an ethnographic case study. Digital bonding is based on traditional values of intra-group solidarity and social engagement as practiced in the electronic domain. In digital bonding, the visual presentation of self appears central (see also Nakamura, 2008).

Digital bonding is established in the digital domain through activity in digital communications, such as telephone and video calls, email and social media postings. Especially in social media, visual representations of oneself are needed. Through visuals, the communication partners are given faces, gendered bodies, social locations and ethnocultural contexts through the semiotic codes embedded in these images, which pinpoint the persons varyingly into different cultural and social orders. Such encoding can be subtle or pronounced, real or fictional, intentional or not, but audiences viewing the photos will interpret and decode any embedded meanings in their own ways, frequently ignoring any original motivations of these images. These and any other photographs will in the net encounter a shared destiny: any intended meanings or purposes of visuals become continuously decoded, reconstructed, commented and challenged in the repeated viewing situations, which are open-ended and cannot be controlled.

Yet, the presence of visuals in the digital domain localise the persons in them in actual life worlds that expand beyond the digital. Digital bonding inflates and strengthens the existing social networks persons and groups are involved in, often with economic consequences such as in business. The increased reachability of persons and information across distances allows for improved agency of persons and groups to promote their goals - and to develop their digital bonds with others. For persons, the visuals tend to make this digital bonding more involved and committing, the way bonding should be between people - "like in real life", except that the digital domain is already a part of it.

Digital bonding transforms and modifies the existing cultural and social orders through the introduction of new actors, the moderators with digital skills and new forms of social agency, in the social settings people live in. It is evident that such challenges to any existing orders originate from younger generations that are increasingly urban, educated and skilled in digital technologies. Through digital practices, these younger ones are contesting existing statuses of rank, seniority and gender, when they create alternative spaces for social and cultural action in the digital domain. They also create contemporary visual identities for the wider group alongside fresh ways and techniques of their representation.

A core element in any identity construction is its visual representation (e.g. Gilroy, 1992; Hall \& du Gay, 1996; Nakamura, 2008). This article valorises aspects of digital visuality in terms of related cultural identity processes, which have led to the development of cultural identities in the digital domain, or digital cultural identities. My focus will be on digital visual identity construction in a dialogue with existing "pre-digital" cultural values and identity representations. The theme will be approached through an ethnographic case study from Oceania, which is a study of Bellona and Rennell Islanders from Solomon Islands. The basic attempt, here, is to better understand how digitality is shaping and articulating cultural identities among this group and what are the roles of visual representations in this process. The ethnographic context of this analysis is the eleventh Festival of Pacific Arts (FOPA 2012), organized in the Solomon Islands capital Honiara.

\section{The Ethnographic Setting: FOPA 2012}

In July 2012, altogether 27 different Pacific nations came together for two weeks in Honiara 


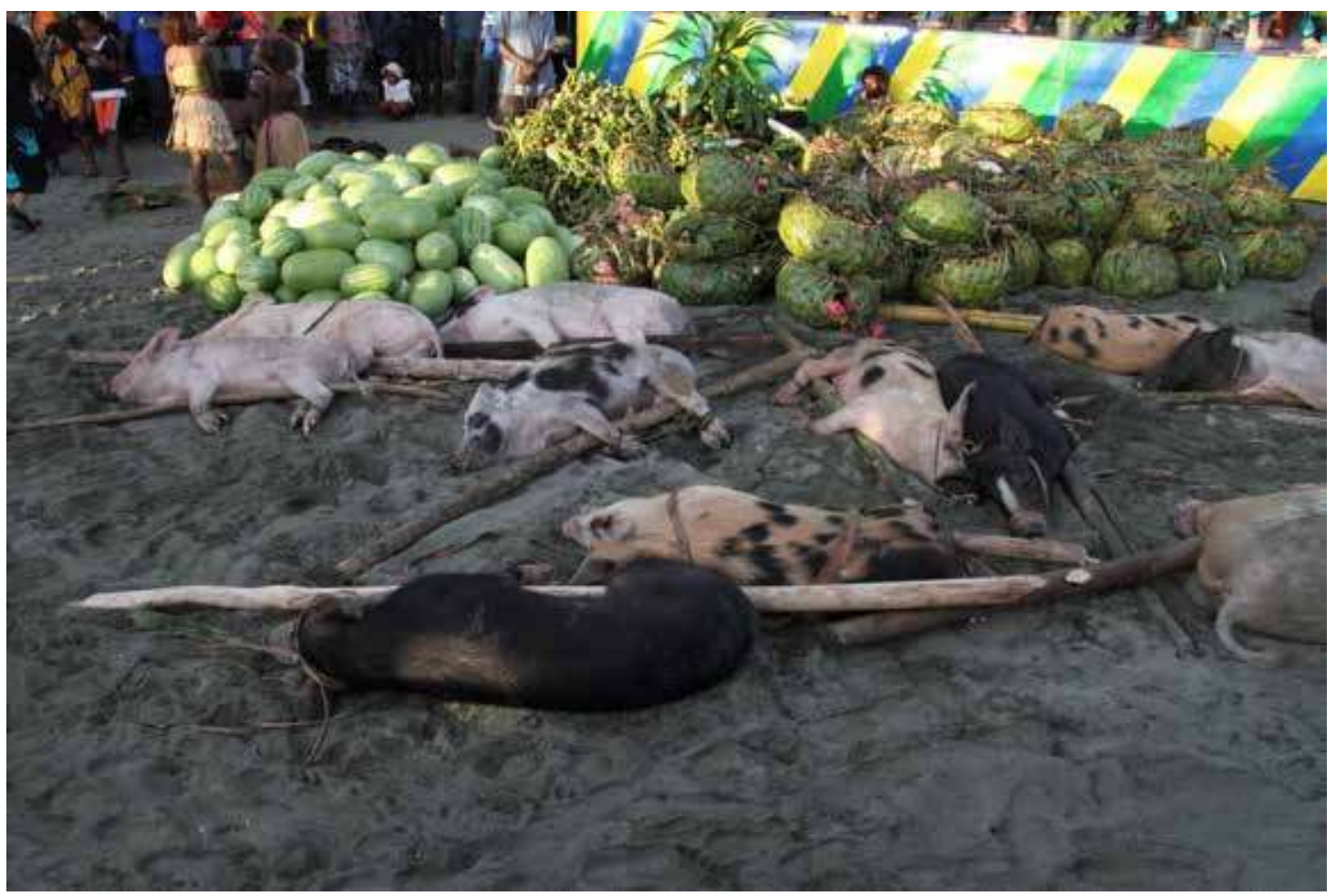

Рното 1. - Traditional welcoming gifts of pigs, betelnuts, and vegetables waiting for distribution at the FOPA Cultural Opening at Ranadi Beach (C) Jari Kupiainen, 2012)

to express and articulate their traditions in their present forms for other Pacific Islanders, who constituted most of the audience. The Festival of Pacific Arts was originally initiated in 1972 by the South Pacific Commission, and it is presently administered by the Pacific Cultural Council. It is a travelling festival and each time held in a different Pacific location. The festival's idea is to fight against the erosion of traditional culture and its expressive forms across the Pacific, and the festival programs are composites of diverse cultural skills and expressions that only occasionally collide with established western art genres and styles (See also Henry \& Foana'ota, 2015). In the Honiara FopA festival, these articulations of Pacific traditions eventuated on and off the festival programme and venues, distributed across Honiara and even the different provinces.

A few background notes about Solomon Islands are in order. This former British colony from 1897 to Independence in 1978 is a complex mixture of over 80 different indigenous groups and languages with complex local histories of traditional warfare and trade alliances that resonate even in the present. There is also the collective memory of World War II that once devastated the archipelago and continues to spoil and poison the environment today, followed by a challenging process of national independence from 1978 onwards. This period includes an armed ethnic conflict and civil war over Honiara and much of the country from 1999 until 2003, when the troops of the Regional Assistance Mission to Solomon Islands, the RAMsI, led by the Australian and New Zealand military, invaded the country and eventually pacified the situation (Allen et al., 2013; Fraenkel, 2006; Moore, 2005). The international military presence in Solomon Islands continued until 2013, when the last military units left the country. Solomon Islands is mainly a Melanesian country with Polynesian (altogether $4 \%$ ) and other minorities in a total population of roughly 500000 inhabitants located in nine provinces.

During the FOPA 2012, the host country Solomon Islands was still under RAMSI occupation and only slowly recovering from the recent upheavals. Therefore the organising of the FOPA 2012 festival as a major inter-provincial and inter-ethnic operation was in itself a huge matter in Solomon Islands. It was a pronounced act of national and local reconciliation and inter-group healing, and the FOPA 2012 carried a symbolic significance for the whole nation. In the festival, even traditional reconciliation rituals and ceremonies were organised among groups. Although the festival audience witnessed these acts that took place publicly, at bottom there were real enmities to be settled, which transformed these events beyond mere festival entertainment acts. The fact that these ceremonies were in the open and free for photographic documentation tangibly epitomised this collective national and even regional healing process. Such imagery also 


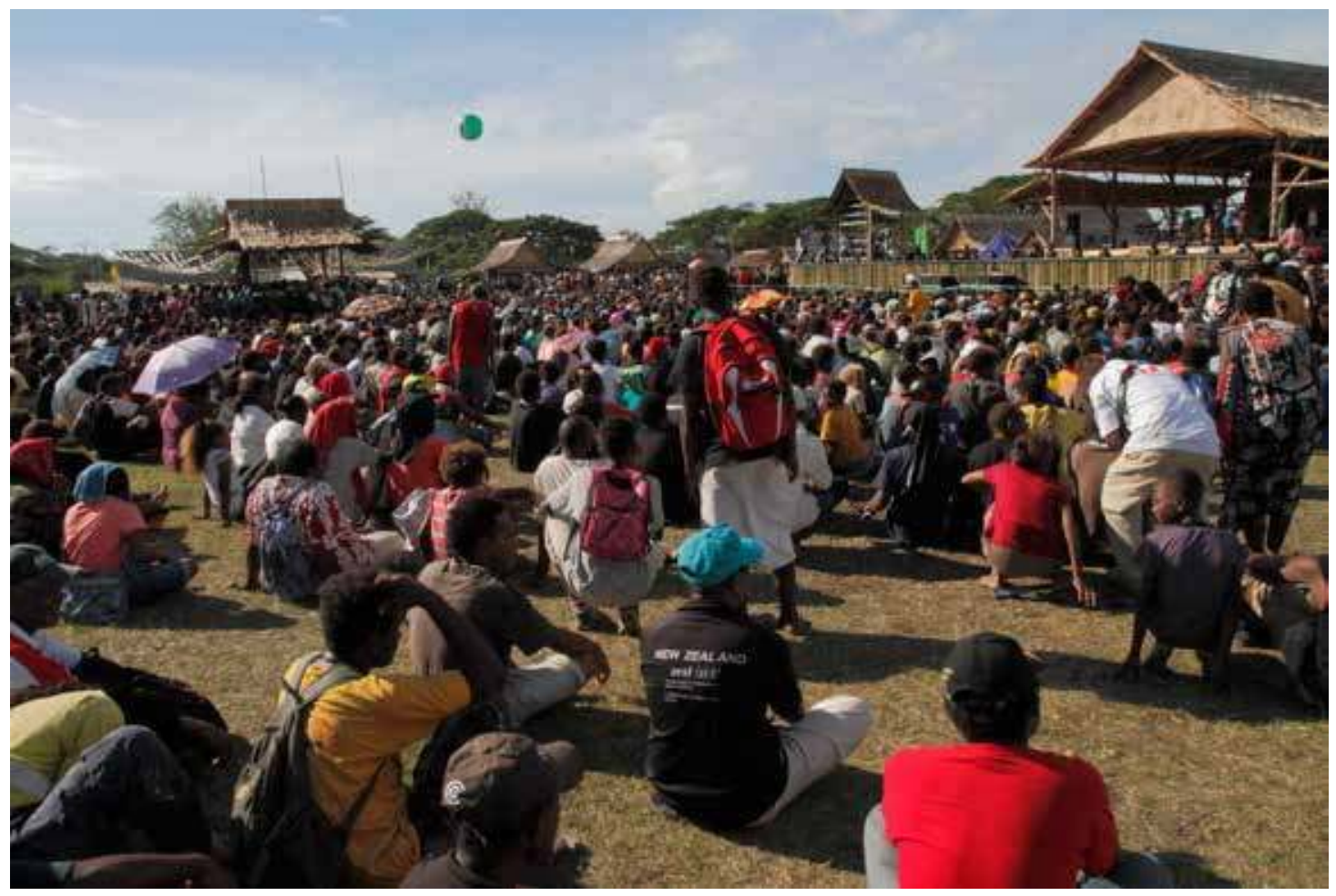

Рното 2.- Festival audience following a performance on the Pasifika Stage(@ Jari Kupiainen, 2012)

appeared in local news media with the spotlight on ceremonies, gift presentations and the dignitaries of delegations - thus giving the national political interests and views much visual foreground under the guise of culture festival reporting.

The FOPA 2012 brought to the capital city Honiara and to satellite venues across the provinces some 3000 international visitors from the 27 participating Pacific countries, yet the vast majority of people in the festival were Solomon Islanders. The main venue, Festival Village in Honiara, saw up to 17000 daily visitors in the free events running from $9 \mathrm{am}$ to $9 \mathrm{pm}$. The average daily number of visitors in all venues put together was 20 000. For Solomon Islands, the festival was the largest event and saw the greatest influx of people since World War II.

All available locations and resources across Honiara and beyond were mobilized for the festival. A large auditorium was built for the National Museum to act as a main side venue for the FOPA, accommodating a film festival, discussions, theatre and dance performances, literature readings and exhibitions. Photography exhibitions were displayed at the University of South Pacific Honiara Building. The National Art Gallery hosted painting and sculpture exhibitions and a cultural village, where Solomon Islands craftspeople displayed and sold their works. Also, provincial side venues had some international Pacific performance groups touring them, the festival's cultural opening was held on a beach venue in Ranadi, and the ceremonial opening and closing events took place at the Lawson Tama rugby stadium. However, the main festival location was the Festival Village.

The Festival Village was a large fenced area in eastern Honiara divided into two sides, the Pacific and the Solomon Islands side. Both had main stages, the Pasifika Stage and the Lakeside Stage, respectively, the latter named after a large artificial lake built in the area facing the houses of the nine provinces, where cultural performances and other activities of local groups went on throughout each day. In the Pacific side, each representing Pacific country had their own house to demonstrate their cultures and traditions, and the Pasifika Stage hosted mostly international performances, especially dance and music acts, whereas Solomon Islands groups mainly performed at the Lakeside Stage.

\section{Photography and video at the FOPA 2012}

The Honiara festival was all about producing, reproducing and transforming Pacific identities (see also Henry \& Foana'ota 2015). Much of this identity work took an explicitly visual form, which the festival context fully supported. Cameras were ubiquitous and shooting was continuous both in photography and video, yet most of this was done with cheap mobile phone cameras and digital 


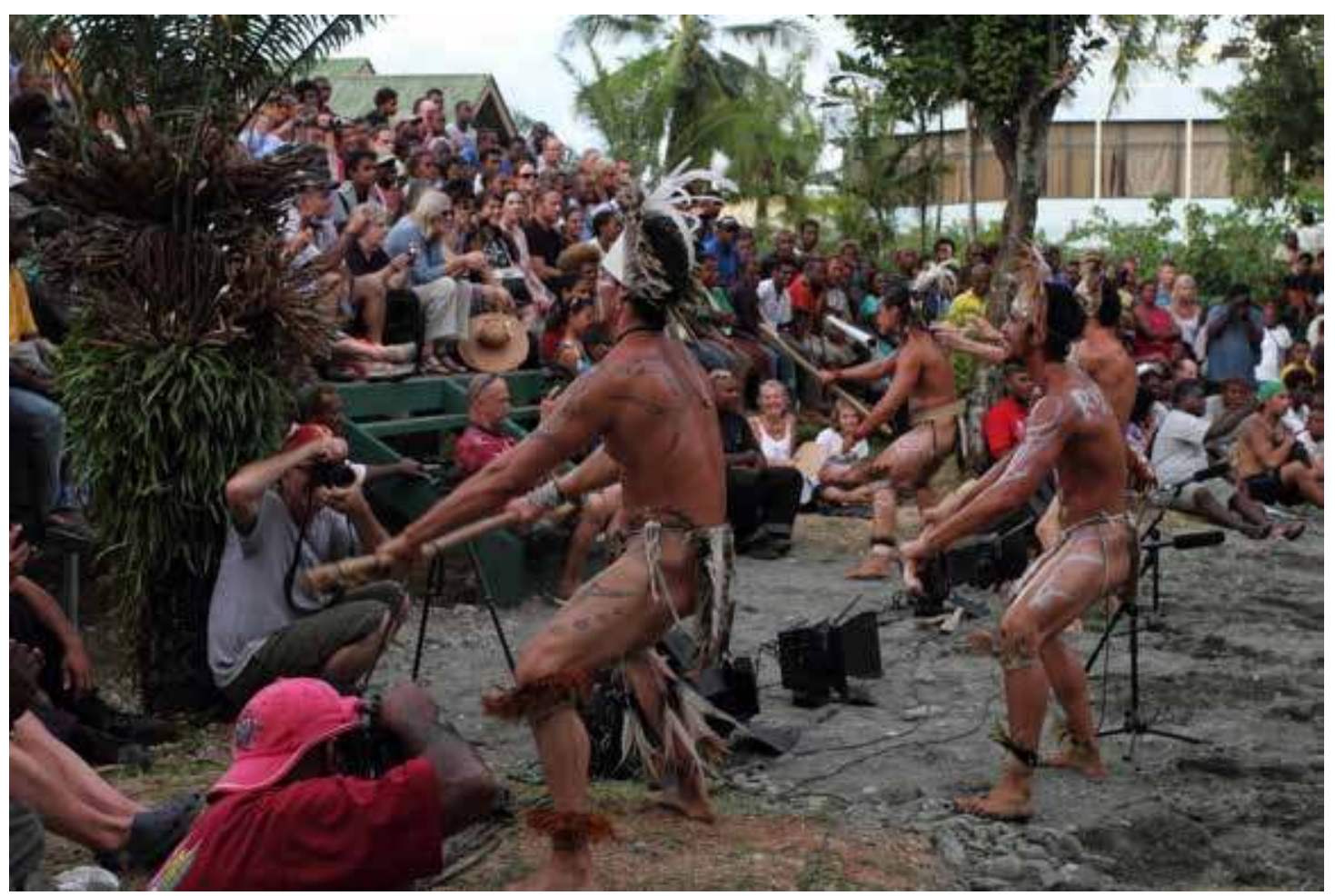

Рното 3. - Rapa Nui dancers performing at the Solomon Islands National Museum yard during the FOPA (C) Jari Kupiainen, 2012

compact cameras handled by almost everyone among the audience - and among the performers and the organizers as well. Some registered film crews, mine included, were documenting festival events for various professional purposes, but the main visual body of documentation of the festival resulted from these non-professional private visual documentation activities among the audience. They were quickly transformed into YouTube, Facebook and offline video files, Flickr photo albums and countless other forms and formats shared among and between Pacific communities online and offline. These visuals relate directly to visual representation of cultural identity, and the festival provided a rich field for observing how the different digital gadgets suitable for visual documentation have become contemporary tools for cultural self-definition, agency, empowerment and social bonding.

The festival organization required the accreditation of all professional media and audiovisual documentation crews including researchers. There were two categories with corresponding accreditation fees, for commercial and noncommercial productions. My crew of three with Barry Pugeva and David Makaua from Bellona belonged to the latter category, and I also had the research permit from the Ministry of Education and Human Resources Development, which explicitly stated that we were shooting a research documentary about the festival's backstage as part of my anthropological research project, which was a non-commercial production. This granted us an open access everywhere in the festival including on and off-stage, dressing and accommodation areas, and even the festival offices. Although we did not push this accreditation to its limits, access everywhere made our work more fluent. This "backstage" focus also allowed me opportunities to observe festival photography methodically, and some of this material has since been included in my research films (Kupiainen 2013a; 2013b; 2014a).

In terms of my original documentation plans, the "festival backstage" theme immediately appeared too broad because there were numerous "backstages" happening in different places simultaneously. Therefore I speedily narrowed down my focus only on the artists of Bellona and Rennell Islanders in the festival. Even that was a challenging topic to cover, because there were a number of Rennell and Bellona artists and performing groups attending the event. Yet, it was more manageable for our small crew, and it also corresponded with my long-term research interest on Bellona and Rennell arts (e.g. Kupiainen 2000; 2014b). I was also staying with my Bellonese friends in a Rifle Range household in western Honiara, spending my time in Honiara mainly among those involved with the festival as artists or organizers. Rifle Range and the adjacent White River areas are largely occupied by Polynesian groups, especially those 
from Bellona and Rennell. My accommodation arrangement provided me opportunities to observe the various social uses of photos and videos taken in and out of the festival that the Rennell and Bellona Islanders were sharing among themselves and with other Pacific Islanders attending the event. The visuals were also posted in various social media platforms, especially the Facebook. In this text, these social uses are analysed in terms of digital bonding.

In comparison with the first Melanesian Arts and Cultural Festival held in Honiara in 1998, which is the second largest cultural event in the Solomon Islands national history and which I have analysed previously (e.g. Kupiainen 2007; 2011), the FOPA 2012 was not only strikingly similar in many ways, but also different. The FOPA was much grander in scale than the Melanesian festival and it brought a Pacific-wide audience and representation, whereas the 1998 festival had only Papua New Guinea, Vanuatu, Fiji and New Caledonia (Kanaky) represented in addition to the hosting Solomon Islands audiences. Yet, the FOPA festival logistics, timetables, provincial group accommodation, ethnic biasing in organization, financial management and other such issues frequently seemed to replicate events during the Melanesian festival in 1998.

Only particular Solomon Islands ethnocultural groups were represented in the FOPA organizing committee, and some of this biasing was reflected even in the FOPA program. Rennell and Bellona compose roughly one per cent of the Solomon Islands population, but they had an important role in the different organizing and planning activities, and in terms of their population size, their artists were "over represented" in the event. However, a few Rennell and Bellona individuals had long-term experience of the different FOPA events and cultural festival organization, so their expertise was employed in the FOPA 2012. Groups excluded from the festival organization tended to participate less in the festival: they had fewer artists and activities in the FOPA and less motivation to attend the festival as audience. The Solomon Islands Western Province representation in the festival was dominated by groups from the Roviana Lagoon with the result that only a few of their neighbours from the Marovo Lagoon appeared in the Festival Village either as artists or audience. Instead, many of them spent their festival fortnight away from the Village selling their crafts and artworks in downtown Honiara at the Art Gallery yard.

In the context of other Pacific cultural festivals I have attended and studied, specifically the FOPA 1992 in Rarotonga, Cook Islands, and the Melanesian Arts and Cultural Festival of 1998 in Honiara, definitely different in the FOPA 2012 was the fact that video and photography had become everyone's activity. In the last few years, the flux of digital communication technology has covered even the most remote islands in the Pacific and digital gadgets such as camera phones and digital compact cameras have become ubiquitous. By now, almost everyone has a camera of sorts especially in urban and semiurban Pacific contexts. The presence of cameras and shooting for diverse purposes and ends was thus ever-present also in and out of the FOPA 2012. In the Festival Village, there were only few strictly controlled photography spots. These spots were on top of the Pasifika Stage, where mostly international artists performed, and also the huge photography tower built opposite the Pasifika Stage but about 200 meters away. The tower was located quite far for documentation of stage events, so only few accredited media people used it. Instead, the tower served as a vIP resting spot. Most events, performances, stage-sides, backstage areas and such were within everyone's camera reach.

The earlier FopA 1992 and Melanesian festival in 1998 had a media accreditation, and practically all professional photography and filming was confined to a small group of various international professionals (e.g. journalists, documentary filmmakers, anthropologists). Apart from these professionals, hardly any locals held any photographic equipment in either festival, and only a few snapshots were taken among the audience. It was still the pre-digital era of emulsion film, which was expensive to process and print especially in the Pacific Islands context, and therefore shots were only sparsely taken, if at all. To exemplify this, the about 40 persons representing Bellona and Rennell at the FOPA 1992 in Rarotonga did end up with some snapshots from the event, but not many: they took altogether maybe some 60 photos. By now, over 20 years later, most of those 60 prints and negatives have decomposed in the tropical conditions of Solomon Islands and disappeared (see also Wright, 2013). However, the deteriorated photographs have been gradually transformed and incorporated into local stories and narrated memoirs, and the visual mementos of Rarotonga events are becoming remembered and imagined as oral history narratives - with the deteriorated photos as memory aids.

In comparison with the 1998 Melanesian Festival, the FOPA 2012 framework for photography and video was altogether different. In addition to accredited professionals, next to everyone in the audience and among organizers was busily documenting the festival events and people with whatever devices they had: phone cameras, digi-compacts, handicams, tablet cameras, DSLR and professional video cameras. Although media accreditation secured access to all assigned shooting locations such as stages, one would find there not only professional crews but also anyone from the festival organization 


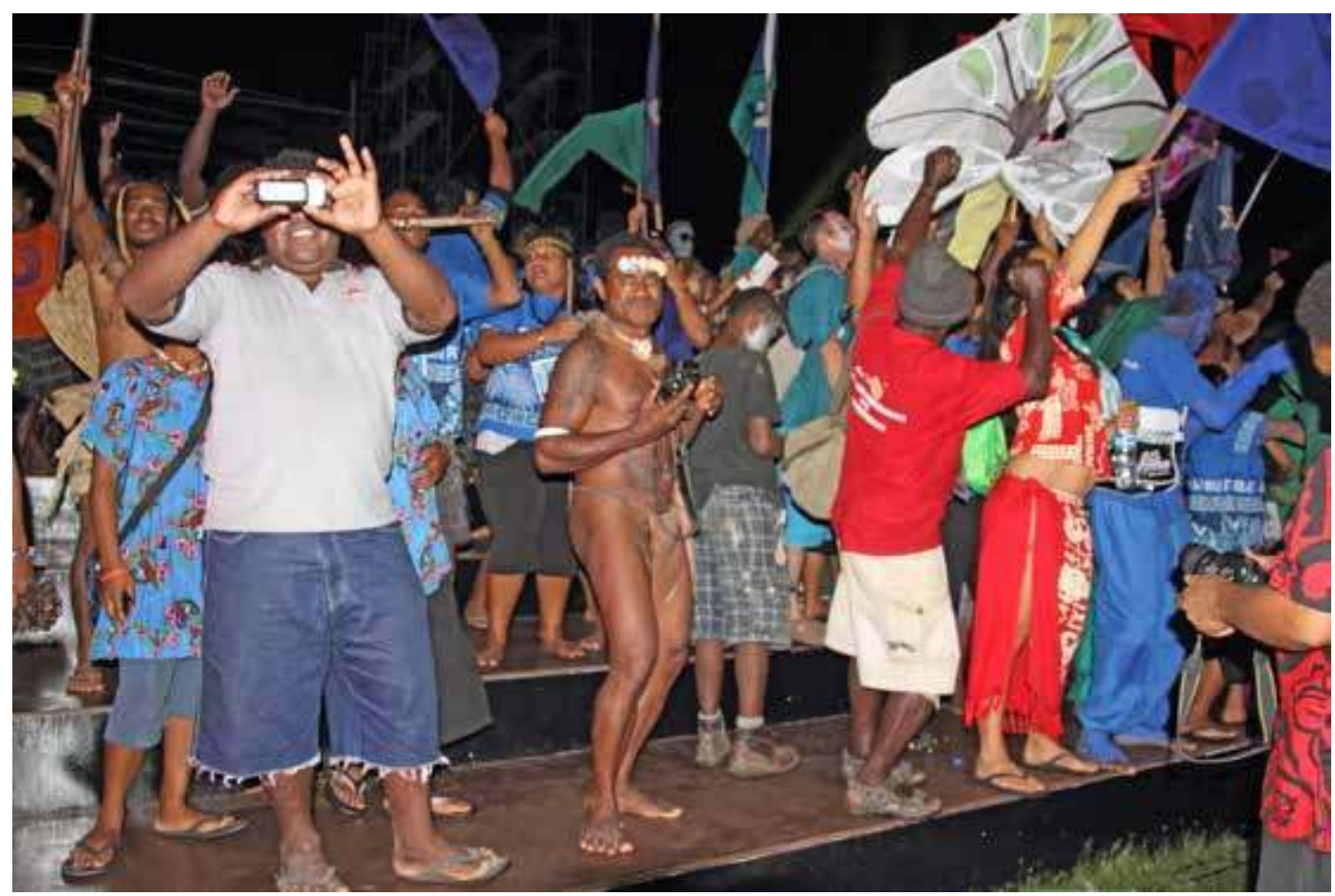

Рното 4. - Festival audience partying in the Festival Closing (Ohoto Barry Pugeva,2012)

including their relatives - each holding cameras. In other words, in most shooting occasions the media accreditation brought us little advantage because we would have been able to access these locations even without any accreditation, just like most other people did. In fact, the camera gear was the access card itself: when people including security saw you taking photos or shooting video, they would make way (or start posing) as opposed to stopping or restricting your shooting.

The accredited media had to comply with either non-commercial or commercial category restrictions. Both accreditations had to follow explicit restrictions in terms of copyrights and the publication of materials in different media channels and formats. We can expect that the accredited media has been complying with and following these accreditation terms during and after the event. However, none of this applied to the general public attending the festival events and performances. They did what they wanted with the images they took and paid no attention to issues such as shooting rights, copyrights, intellectual and cultural property rights. The first Facebook and YouTube postings took place as soon as the festival started, and people kept on posting on the Internet throughout the festival and afterwards, when edited videos from the festival started to pop up in the net.

Photos and videos were not only posted in the net, but many creatively crafted local applications were done privately and semi-privately as well. In my Rifle Range household I was able to observe a particular usage of these visuals in a format that seemed popular in wider Honiara as well, and some examples have since appeared in (and disappeared from) YouTube. Namely, the young men in the household were interested in photography and they had a couple of digital compact cameras, about 5 MPix size. They kept on shooting topics of their interests throughout the festival, and at the house they used freeware slideshow software to compose "films" or "music videos" out of the slideshows of photos. To these photo slideshows were then added texts and graphics of their choice, with a hot pop track of Pacific music to turn the slideshows into "music videos". Although crudely made and finished, and lacking any narrative plots, these videos were watched over and over again with varying audiences in Rifle Range and elsewhere. For an anthropologist, these videos opened for analysis some culturally specific ways of seeing and visuality in rough everyday-like formats, which were essentially peer-to-peer intragroup communication rather than targeted for any cultural outsiders.

The themes and titles of the slideshow videos were mundane and often bordered on the banal. For example, during the first festival days, one of my friends made a hugely popular video in the neighbourhood titled "The Polynesian Girl". 
It consisted of a photo slideshow of attractive looking young women of various Polynesian origins posing for the camera during the FOPA festival. The soundtrack was a current pop title by the Bellonese singer Jah Boy: "Polynesian Girl", and text add-ons included expressions of love and admiration of beauty towards Polynesian girls from the different Pacific Islands. Superficially observed, the piece appeared as a male sexual fantasy video only. Yet, during the tens of times I participated in the viewings that frequently took place outside my room in the household, and thus not to be avoided, I was able to observe more. Indeed, there was the sexual gaze involved, but it gradually transformed into more complex issues of Bellona-Rennell cultural ideals in coupling underneath the seemingly straightforward sexual innuendo.

Among Bellona and Rennell Islanders, like among other Solomon Islanders, modernity and especially urbanization in Honiara have brought about fundamental changes in the group's social structure and situation. One such aspect is the issue of endogamy versus exogamy; should one's spouse originate from own or other cultural group. Bellona and Rennell Islanders were mainly endogamous until World War II and the advent of Christianity on their islands. After war, wage-labour and migration to plantations and Honiara (in a Christianity framework) have transformed them increasingly exogamous, and inter-group marriages have emerged ever since the war. (Monberg 1966; 1991.) By now, exogamy is common, yet at the bottom underlies the ideal of endogamy, the notion to look for a spouse within one's own group - if not from Bellona and Rennell, then at least from other Polynesian groups. It is culturally more acceptable to look for a Polynesian spouse than a Melanesian one, although Bellona and Rennell Islanders generally approve of any inter-group marriages today.

From the perspective of endogamy, the "Polynesian Girl" video resonated between the traditional cultural values and the present sociocultural situation this youth is facing, and the video articulated one culturally approved point of view for other Bellona-Rennell, both men and women, to consider. Also women watching the "Polynesian Girl" seemed to enjoy it, as evidenced in their repeated viewings. The women's comments while watching responded mostly - and frequently with sarcasm - to the male biased beauty ideals that the video reflected, and also on the attending young men's attitudes and responses to the images in the video. Women were indeed sharp in observing these responses, which provided much discursive and emancipatory ground for teasing the men for their attitudes. These viewings were also testing grounds for potential future partnerships.
Underneath the casual commentaries there happened different mating plays among the attending men and women, and the video provided a useful framework to spy on potential partner responses at specific moments in the slideshow video.

My friend accomplished the "Polynesian Girl" video with a clear idea of showing it not only to other (young) men of his own cultural group but also to women as well. He had a definite personal strategy and motivation here, which involved digital visual tools and means that were purposefully activated for his objectives. The video demonstrated to others his visual skills and ideas concerning the gendered representation of "culturally approved" others, which here translated as young women from other Polynesian groups and reflected my friend's personal but culturally motivated beauty ideals. The audience approval of my friend's visual strategy was evident during the viewings and subtly enforced the ideal of endogamy among them. The audience responses also prescribed a specific Polynesian identity articulated and defined in contrast to, e.g., Melanesian and other non-Polynesian identities. It will be worth pointing out that the "Polynesian Girl" was completed already during the first festival week, and my friend and his mates spent the latter festival week - with obvious motivations - scouting for those Polynesian girls who appeared in the video. The "Polynesian Girl" video demonstrated a particular digital visual technology enabled strategy. It was culturally motivated, organized and employed for intragroup bonding, a particular offline technique of digital bonding, that is.

For a visual anthropologist, the "Polynesian Girl" watching settings provided much information of the gendered approaches of particular persons in actual situations, where visual representations of cultural identity were in question. The local and Western beauty norms, the sexual preferences, the various impediments for a successful pairing and also the potential opportunities for success, were all outlined, laughed at, reflected upon, explicitly analysed and also criticized in these numerous reflections during the different viewings of the "Polynesian Girl". It was evident that these Bellona-Rennell youth were representing and expressing value systems that contained elements from cultural traditions and Christianity, as well as elements of wider popular and media culture. Here, they were applying digital technology to express their current values, identities and mating strategies, and the visuals were employed in providing currently applicable interpretations of the traditional cultural ideal of endogamy. In this, they were using narrative and expressive content motivated by their own cultural values, 
which were both traditional and contemporary - "jiving to the world beat while making their own music," as Marshall Sahlins (1993: 19) would say.

\section{Selfies and Digital Bonding}

Basically, camera consciousness can or cannot be seen from the images. In practical photography and video, this translates into the question of posing or acting for the camera. Apart from studio photography, a predominant convention is that professionally oriented visual documentarists try to avoid posing (observational mode), whereas people shooting for their private albums and memory collections specifically want to pose for their own cameras, to have their portraits taken at a specific spot, scenery, or company (also, e.g., Chalfen 1987; Sarvas \& Frohlich 2011). The primary purpose of the portrait shot is to serve as evidence for the person's later narrative relating to the event of photography (spot, scenery, company), and the photo is also a memory aid. Presently, this posing motivation has reached gigantic proportions in the worldwide phenomenon of selfie photography, boosted by the global distribution of mobile phone and other digital cameras in parallel with social media services as digital publication platforms. In the FOPA 2012, selfies and other posed photography and video shots were thus happening all around the place. The Festival Village held even an official photography spot with festival logos and a graphic background, which was a popular posing site for festival visitors.

Posing and selfies were explicitly social activities that during the festival were mobilised in building connections and networks with others, and in solidifying existing relationships. Solomon Islanders generally thought of the FOPA 2012 as a once in a lifetime event, so locals tried to make their most of it by bonding actively with other Pacific Islanders. Cultural exchanges in these encounters typically included also the sharing of visuals between parties. These photos and video clips were usually taken with all the different cameras present and later shared in social media and emails, and as file copies on USB memory sticks. The photos usually depicted not only faces of persons but especially their cultural particularities, such as tattoos, jewellery, traditional garments and other objects that revealed the cultural associations and backgrounds of the people represented in them.

Posing for a photo reveals something of the person's values and ways of thinking, especially in terms of her external and visual appearance. It is probably worth thinking for a while with

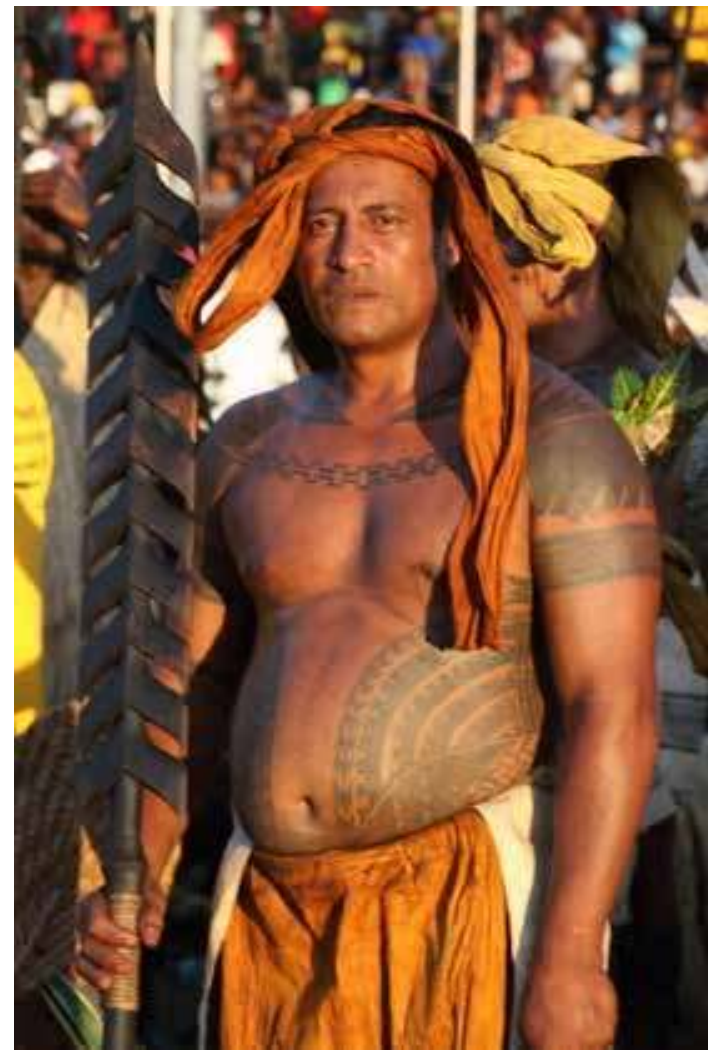

Рното 5. - Puia Tapuika from Bellona photographed during the FOPA. He is wearing the traditional tattoos and dress together with the ceremonial tao hakasanisani spear used in traditional rituals (C) Barry Pugeva, 2012)

Erving Goffman's The Presentation of Self in Everyday Life (1956) added with Judith Butler's (1990) ideas of the performativity of gender: In posing, there are roles, there is performance, there are ideas of influencing others through one's presence and one's visual appearance, there are context-bound interpretative rules actively at play, and there is drama. All of this is gendered. For example, when young BellonaRennell women pose backstage together with sweaty traditional Maori male dancers from New Zealand who had just finished their stage performance, the young women demonstrate not only their cultural ideals in performance and play. The women also expose their bodies, personalities and background cultures to an external gaze, which is fixed and made permanent in the act of photography. These expositions can be utilised for different purposes. For example, these women can later show their Maori poses and selfies to their friends and enforce ideal identities of themselves through these photos not only at home through camera and laptop screens, but especially on Facebook, where such photos are frequently posted - as presentations of digital self in everyday life, so to speak. Posing 


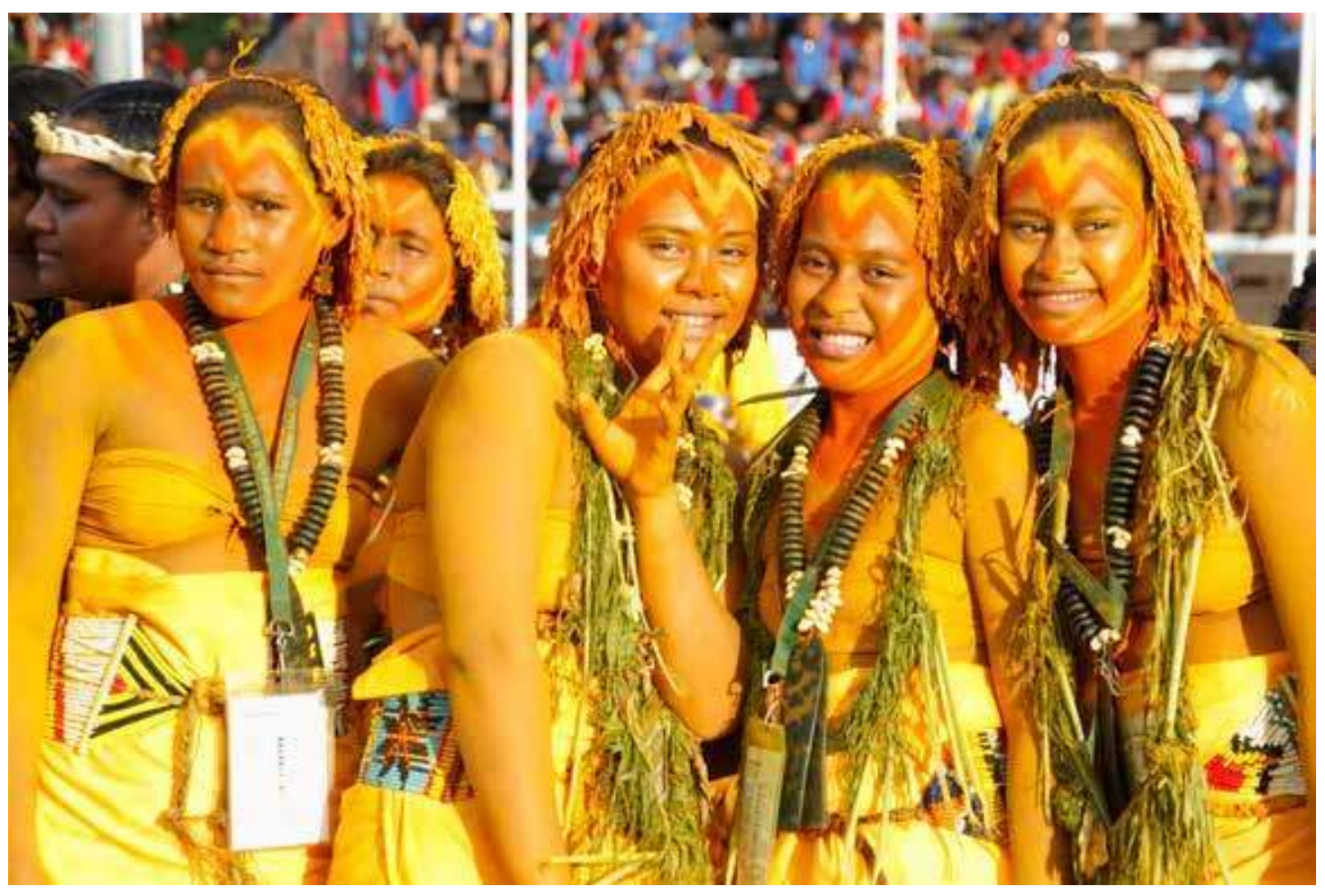

Рното 6. - Young women from Ontong Java (Solomon Islands) dressed in traditional costumes and posing for the camera during the FOPA Closing (C Barry Pugeva, 2012)

is empowering.

Yet, posing is also hazardous in the digital environment of the net, because the resulting photos and videos will endure in the digital domain, reaching viewers, audiences, uses and meanings that cannot be truly anticipated at the moment of their original release. Visuals in the digital domain are also prone to exploitation by commercial and other actors, who may at any later point of time gain access to the materials. Personal visuals in the net seem to resemble tattooing designs in skins in the sense that any meanings their owners assign them may change over time, yet they cannot be conveniently removed from sight afterwards. Whatever appears in the net tends to remain there.

\section{Discussion}

The digital visual presentation of self in the net provides Bellona and Rennell Islanders with opportunities to introduce fresh social dynamics in the relevant community, which is becoming increasingly mobile and distributed in different geographic locations not only in Solomon Islands but internationally. Those active in the digital domain will soon assume communal roles as cultural and social mediators, who in their everyday communication activities gradually introduce more international values, practices and technologies to the wider group (Kupiainen 2004). Although someone might interpret such developments as cultural and social erosion caused by advancing global technologies, I would rather emphasize the local motivations involved in the activities. At the centre, here, is the motivation of digital bonding.

The FOPA 2012 festival demonstrated the practically universal presence of digital photographic technology and how individual and cultural uses of images have not only entered into but also diversified the pragmatic and semiotic domains of image production and consumption in Solomon Islands and the wider Pacific. If this translates in the global digital industry as fresh customer groups bring in fresh ideas for using products, which can be turned into revenue, then be it. Yet, for Rennell-Bellona and other Solomon Islanders, at least, the photo gadgets open genuinely new ways and modes of self-expression, cultural empowerment and agency. Digital images are suited for and compatible with existing online communication technologies, which allow for an instant global distribution of these images. Pacific communities use these images primarily for viewing and distributing them within their own diaspora groups and only secondarily to represent themselves as a group to the wider world. Therefore these images function primarily 
to maintain one's family and group relations through digital bonding.

Modernity emphasises the individuality of persons as opposed to pre-modern or traditional settings, where individuals may become identified as members of a group or a collective. This traditional setting would indicate that the person's identity is socially relational, the sum of the different social networks the person belongs to, as has been analysed in Melanesia (Strathern, 1990). Digital modernity may be said to reinforce individuality further through digital identification of persons with technology and software, such as with individual usernames and accounts. As Miller \& Horst (2012: 4) point out, digitality "is becoming a constitutive part of what makes us human." This would also indicate that the digital identity of a person, including the visual representations, is constitutive to contemporary humans. However, in this process, a person's individuality as a social agent and being becomes emphasised and foregrounded over the traditional cultural setting, where identities are socially shared and represented as group rather than as individual identities. The FOPA 2012 demonstrated how the contradicting ideas of collectively oriented traditional and individually oriented modern cultural identities are integrated in the visual documentation activities among the audience. Although the digital domain enforces the identification of individuals as separate entities rather than as members of groups or collectives, most FOPA 2012 participants were actively recording images of themselves and others as members and representatives of particular cultural groups and collectives, people conscious and proud of their distinctive cultural identities.

\section{BIBLIOGRAPHY}

Allen Matthew, Sinclair Dinnen, Daniel EvANS and Rebecca Monson, 2013. Justice Delivered Locally. Systems, Challenges and Innovations in Solomon Islands, Washington, World Bank.

ButLer Judith 1990. Gender Trouble. Feminism and the Subversion of Identity, London \& New York, Routledge.

Chalfen Richard, 1987. Snapshot Versions of Life, New York, Popular Press.

Fraenkel Jon, 2005. The Manipulation of Custom. From Uprising to Intervention in the Solomon Islands, Canberra, Pandanus Books.

Hall Stuart \& Paul du Gay (eds), 1996. Questions of Cultural Identity, London, Sage.
Henry Rosita \& Lawrence Foana'ota, 2015. Heritage Transactions at the Festival of $\mathrm{Pa}$ cific Arts, International Journal of Heritage Studies 21, 2, pp. 133-152.

Gilroy Paul, 1992 (1987). There Ain't No Black in the Union Jack. The Cultural Politics of Race and Nation, London, Routledge.

Goffman Erving, 1956. The Presentation of Self in Everyday Life, Edinburgh, The University of Edinburgh.

Kupiainen Jari 2000. Tradition, Trade and Woodcarving in Solomon Islands, Helsinki \& Höjbjerg, The Finnish Anthropological Society $\&$ Intervention Press.

—, 2004. Internet, Translocalisation and Cultural Brokerage in the Pacific, in J. Kupiainen, E. Sevänen \& J. A. Stotesbury (eds), Cultural Identities in Transition. Manifestations of Change in Local and Global Culture, New Delhi, Atlantic Publishers, pp. 344-362.

—, 2007. Kastom sur scène n'est pas coutume mise en scène. Réflexions sur le premier Festival des Arts et de la Culture mélanésiens, in B. Glowzcewski \& R. Henry (eds), Le défi indigene. Entre spectacle et politique, Paris, Éditions Aux Lieux d'Être, pp. 235-255.

-, 2011. Kastom on Stage is not Staged Custom: Reflections on the First Melanesian Arts and Cultural Festival, in B. Glowzcewski $\&$ R. Henry (eds.), Challenge of Indigenous Peoples. Spectacle or Politics?, Oxford, Bardwell Press, pp. 187-203.

-, 2013a. Bellona at the FOPA, 9 min., Jari Kupiainen / Jape Films (not in commercial distribution; contact the author).

—, 2013b. Imaging the FOPA 2012, 11 min., Jari Kupiainen / Jape Films (not in commercial distribution; contact the author).

-, 2014a. Kastom Twelve - Rennell and Bellona Artists at the FOPA 2012, 54 min., Jari Kupiainen / Jape Films (not in commercial distribution; contact the author).

-, 2014b. Artistic Bellona in the Contemporary Art of Solomon Islands, in B. Burt \& L. Bolton (eds), The Things We Value. Culture and History in the Solomon Islands, Canon Pyon, Sean Kingston Publishing, pp. 129139.

Miller Daniel \& Heather A. Horst, 2014. The Digital and the Human: A Prospectus for Digital Anthropology, in H.A. Horst \& D. Miller (eds), Digital Anthropology, London \& New York, Berg, pp. 3-35. 
Monberg Torben, 1966. Religion of Bellona Island. A Study of the Place of Belief \& Rites in the Social Life of Pre-Christian Bellona, Copenhagen, National Museum of Denmark.

—, 1991. Bellona Island Beliefs and Rituals, Honolulu, University of Hawaii Press.

Moore Clive, 2005. The ramsi Intervention in the Solomon Islands Crisis, The Journal of Pacific Studies 28, 1, pp. 56-77.

Nakamura Lisa, 2008. Digitizing Race. Visual Cultures of the Internet, Minneapolis, University of Minneasota Press.
Sarvas Risto \& David M. Frohlich, 2011. From Snapshots to Social Media. The Changing Picture of Domestic Photography, London, Springer.

Strathern Marilyn, 1990. The Gender of the Gift. Problems with Women and Problems with Society in Melanesia, Berkeley, University of California Press.

Wright Christopher, 2013. The Echo of Things. The Lives of Photographs in the Solomon Islands, Durham, Duke University Press. 